ВЕСТНИК ПНИПУ. ГЕОЛОГИЯ. НЕФТЕГАЗОВОЕ И ГОРНОЕ ДЕЛО

BULLETIN OF PNRPU. GEOLOGY. OIL \& GAS ENGINEERING \& MININ

ISSN 2224-9923

Tom/Volume 15 №20 2016

http://vestnik.pstu.ru/geo/

УДК 622.276 .43

Article / Статья

(C) PNRPU / ПНИПУ, 2016

\title{
STUDY OF GEOLOGICAL AND TECHNOLOGICAL MODEL OF COMPLEX RESERVOIRS OF SAMOTLOR FIELD OIL AND GAS DEPOSITS
}

\section{A.A. Chusovitin, A.S. Timchuk ${ }^{1}$, S.I. Grachev ${ }^{2}$}

Tyumen Petroleum Research Center LLC (79/1 Osipenko str., Tyumen, 625000, Russian Federation)

${ }^{1}$ West-Siberian Research Institute of Geology and Geophysics (48 Respubliki str., Tyumen, 625000, Russian Federation)

${ }^{2}$ Tyumen Industrial University (47 Respubliki str., Tyumen, 625000, Russian Federation)

\section{ИССЛЕДОВАНИЕ ГЕОЛОГО-ТЕХНОЛОГИЧЕСКОЙ МОДЕЛИ СЛОЖНОПОСТРОЕННОГО КОЛЛЕКТОРА НЕФТЕГАЗОВОЙ ЗАЛЕЖИ САМОТЛОРСКОГО МЕСТОРОЖДЕНИЯ}

\section{А.А. Чусовитин, А.С. Тимчук ${ }^{1}$, С.И. Грачев ${ }^{2}$}

ООО «Тюменский нефтяной научный центр» (625000, Россия, г. Тюмень, ул. Осипенко, 79/1)

${ }^{1}$ Западно-Сибирский научно-исследовательский институт геологии и геофизики (625000, Россия, г. Тюмень, ул. Республики, 48)

${ }^{2}$ Тюменский индустриальный университет (625000, Россия, г. Тюмень, ул. Республики, 47)

Received / Получена: 07.07.2016. Accepted / Принята: 29.08.2016. Published / Опубликована: 30.09.2016

Key words:

waterflooding, gasless oil flow rates, oil and gas deposits, reserves development, investigated object's model, distribution of productive strata properties, petrophysical studies, barrier at the phase contact border, complex reservoirs, facies analysis, collector texture.
The achievement of project indicators of complex reservoirs' development through integrated management of oil and gas reserves' recovery requires the use of models that adequately reflect the geological structure of the medium, which determines the filtration flows direction during waterflooding. Their reliability increases based on the analysis of lithofacies features of productive part of the cut and enclosing sediments formation, reservoir features prediction in the inter-well space.

It is known that the heterogeneity of macro level (sand content, segmentation) plays a crucial role in the formation of primary directions of reservoir fluid's filtration flows. Microinhomogeneity (anisotropy, lateral variability in the permeability) has an impact on the nature of mass transfer processes, the target fluid's displacement indicators and the phase permeability changing.

Analyzing the the productive section of the $\mathrm{AV}_{1}{ }^{l-2}$ reservoir, which is the most lithologically volatile in the Samotlor field, a special attention was given to textural characteristics (monolithicity and segmentation) of collectors. As a result based on the ratio of two basic parameters Hef $u$ aps, formation reservoirs were classified into three main classes: with massive texture, with thin-layered structure and with mixed texture.

As a re re the results of facies analysis for each of layers, criteria referring to a particular type were formed.

It results of facies analysis for each of layers, criterias $\mathrm{AB}$ aring to a particular type were for It was found that the productive strata gof the roup $\mathrm{AB}$ are characterized by a very complex facies formation environment, which occurred mainly in the coastal-marine conditions, in the areas of semi-enclosed sea gulfs and lagoons, deltaic subtraction of paleorivers. This affected both the nature of the various deposits types distribution and their structure, and resulted in a significant heterogeneity of reservoir properties. The research results allowed to allocate within the considered ayers zones with different facies.

It was found that the most effective barrier waterflooding is in the avandelta area. The influence of reservoir facies affiliation on the effectiveness of the barrier flooding associated with distribution characteristics of interlayers with different permeability and of reservoir segmentation degree was explained.

The recommendations for optimizing the barrier waterflooding techniques depending on the facial characteristics of the area were developed.

Достижение проектных показателей разработки сложнопостроенных коллекторов путем комплексного управления выработкой запасов нефти и газа требует применения моделей, адекватно отражающих геологическое строение среды, определяющей направление фильтрационных потоков при заводнении. Их достоверность повышается на основе анализа литолого-фациальных особенностей формирования продуктивной части разреза и вмещающих отложений, прогноза особенностей коллектора в межскважинном пространстве.

Известно, что неоднородность на макроуровне (песчанистость, расчлененность) играет определяющую роль в формировании преимущественных направлений фильтрационных потоков пластовых флюидов. Микронеоднородность (анизотропия, латеральная изменчивость проницаемости) оказывает влияние на характер массообменных процессов, показатели вытеснения целевого флюида и изменение фазовых проницаемостей.

При анализе продуктивного разреза пласта $\mathrm{AB}_{1}{ }^{1-2}$, являющегося наиболее литологически изменчивым на Самотлорском месторождении, особое внимание уделялось текстурным особенностям (монолитности и расчлененности) коллекторов. В результате коллекторы пласта были классифищированы на три основных класса: с массивной текстурой, с тонкослоистой текстурой, со смешанной текстурой.

В результате детальных исследований особенностей геолого-физической характеристики строения и с учетом результатов фациального анализа для каждого из пластов были сформированы критерии отнесения к оезультав фациаль

Установлено, что продуктивные пласты группы АВ характеризуются весьма сложной фациальной обстановкой их формирования, которое происходило преимушественно в прибрежно-морских условиях, в зонах полузамкнутых формирован, котое приходе пеместен в прибрежно-морских условиях, в зонах полузамкнутых различных типов, так и на их строении и обусловило сушественную неоднородность коллекторских свойств породразличных типов, так и на их строении и обусловило существенную неоднородность коллекторских свойств породпластов зоны с различной фациальной принадлежностью.

Установлено, что наибольшей эффективностью барьерное заводнение обладает в районе авандельты. Объяснен характер влияния фациальной принадлежности участка пласта на эффективность барьерного заводнения, связанный с особенностями распределения пропластков с различной проницаемостью и степенью расчлененности коллектора.

Разработаны рекомендации по оптимизации технологии барьерного заводнения в зависимости от фациальной характеристики участка.

Aleksandr A. Chusovitin - Deputy director general (тел.: +00734525500 55, e-mail: tnnc@tnk-bp.com).

Sergei I. Grachev - Doctor of Technical Sciences, professor, Head of the Department of Oil and Gas Field Development and Exploitation (тел.: +7 345 228 30 27, е-mail: grachevsi@mail.ru). The contact person for correspondence.

Чусовитин Александр Александрович - заместитель генерального директора (тел.: +007 34525500 55, e-mail: tnnc@tnk-bp.com). Тимчук Александр С таниславович - заместитель генерального директора (тел.: + 00734524616 15, e-mail: office@zsniigg.ru).

Грачев Сергей Иванович - доктор технических наук, профессор, заведующий кафедрой разработки и эксплуатации нефтяных и газовых месторождений (тел.: +007 34522830 27, e-mail: grachevsi@mail.ru). Контактное лицо для переписки. 


\section{Introduction}

The choice of technology for geologically complex oil and gas fields development is determined by the conditions of their associated occurrence in the formation, absence of impermeable discontinuities at the levels of gas-oil contact (GOC) and water-oil contact (WOC). In order to prevent dissipation of the integrated gashydrodynamic system of deposits, technologies for containment of formation fluids phase contact position shift are applied. For instance, one of them is barrier waterflooding, directed at dissociation of oil and gas reserves and their further independent development, prevention of gas breakthrough into the bottoms of producing wells, increase of gas-free oil production, preservation of pore pressure in the gas cap, and reduction of oil infiltration into the gas cap. To this end, according to the integrated development program of Samotlor field, barrier sequences of injection wells were formed for horizons $\mathrm{AB}_{1-3}$ and $\mathrm{AB}_{2-3}$, which form an integrated hydrodynamically connected and uniquely massive reserve of oil and gas with common GOC and WOC. However, due to the low correlation between technology indicators and geological setting of the development target, partial dissipation of oil reserves occurred.

Lyantor field does not include pure oil areas; water-oil zone contains $12 \%$, and water-oil-gas zone $-88 \%$ of oil reserves. Dispersed 9-point pattern-type inverted water injection system is implemented. Apart from oil-saturated interlayers, injection wells uncover gas-saturated layer for creation of a dispersed waterflooding barrier and water rim at GOC. Analysis conducted by A.V. Makarov [1] indicated significant differences in reserves development for areas with varied geological structure, detected relatively low coverage of $\mathrm{AC}_{9-11}$ productive horizons, uneven recovery of reserves and water adown migration from initially gas-saturated intervals.

The examined fields are in the basic period of development (stage IV), when the previously unsolved problems are augmented by deficiencies in contour waterflooding and unsatisfactory implementation of the designed reservoir development systems. In the opinion of R.H. Muslimov [2], at this stage the main focus of attention should be directed at elaboration of targeted areas geology and differentiated description of the formation. N.N. Lisovskii and R.G. Shagiev [3] state that it is possible only with the advanced multidisciplinary basis of research containing data on properties and parameters of the productive strata. An explanation of physical essence of the production area is required, i.e. a valid model that would not contradict to various research data.

Thus, rational development of oil reserves in the oil and gas fields of Western Siberia (totaling in over 5 billion tons) is possible by means of improving the targeting of geological and production measures by means of productive strata properties detailing. It is topical to substantiate the selection of efficient development systems based on the detailed geological study of the target using special-purpose petrophysical research methods and calculation experiments drawing on the geological filtration models.

Applied tasks of rational hydrocarbon reserves development in multiphase formations were solved by M.T. Abasov, A.V. Afanasiev, Iu.E. Baturin, V.G. Griguletskii, S.N. Zakirov, I.S. Zakirov, B.A. Nikitin, A.N. Laperdin, M.N. Nikolaevskii, N.Ia. Medvedev, I.R. Mukminov, A.N. Shandrygin and other Russian researchers. As a result, it was established that the efficiency of multiphase reserves development systems application depends on the geological and physical structural features of the development target. Therefore, it is required to adapt the technologies tested at other fields to the identified specific geological structural features of the target, e.g. as a result of facies analysis. Reliable data is needed for correlation of development systems efficiency indicators, differentiated choice of technology for complex geology and physical conditions of various oil and gas reserves. A lot of attention was paid to the hydrodynamic substantiation for positioning of horizontal sidetracked wells, their profiles and production cycles. A task has been defined to create barriers at GOC level in order to prevent gas breakthroughs from the gas cap to horizontal parts of production wells draining the oil-saturated part of the reservoir. For some of the targets this measure will improve the efficiency of development systems and facilitate oil reserves recovery.

However, despite the significant amount of conducted scientific researches in this area, currently the problems of various waterflooding 
technologies selective use and efficiency improvement are not satisfactorily solved. Open sources barely reflect the results of research directed at analysis of geological features and well operation mode impact on forming of barriers at phase contact interfaces.

The achievement of project indicators of complex reservoirs' development through integrated management of oil and gas reserves' recovery requires the use of models that adequately reflect the geological structure of the medium, which determines the filtration flows direction during waterflooding. Their reliability increases based on the analysis of lithofacial features of productive part of the cut and enclosing sediments formation, reservoir features prediction in the inter-well space.

\section{Research of Samotlor field $A B_{1-5}$ horizons development efficiency reduction causes}

Analysis of development state for two areas (area 1 is located in the south-east part of the field, area 2 in the north-west part) was performed. The areas have different waterflooding patterns but similar geological profile. Comparison of geological and physical parameters for these areas is provided in [4], presented in Table 1, and the characteristic for the implemented development systems - in Table 2.

Table 1

Geological and physical parameters comparison for areas 1 and 2

\begin{tabular}{|l|c|c|c|}
\hline \multirow{2}{*}{ Horizon parameter } & \multicolumn{3}{|c|}{ Horizon } \\
\cline { 2 - 4 } & $\mathrm{AB}_{1}{ }^{1-2}$ & $\mathrm{AB}_{1}{ }^{3}$ & $\mathrm{AB}_{3-3}$ \\
\hline Permeability, $10^{3} \mu \mathrm{m}^{2}$ & $25 / 4$ & $99 / 137$ & $344 / 190$ \\
\hline Compartmentalization & $6 / 6$ & $2 / 2$ & $6 / 9$ \\
\hline Porosity & $0.231 / 0.190$ & $0.255 / 0.260$ & $0.270 / 0.209$ \\
\hline Sand fraction & $0.66 / 0.69$ & $0.61 / 0.69$ & $0.42 / 0.52$ \\
\hline Net thickness, $\mathrm{m:}$ & & & \\
Gas-saturated & $18 / 18$ & $7 / 5$ & $8 / 8$ \\
Oil-saturated & $0 / 0$ & $1 / 2$ & $14 / 13$ \\
\hline Factor: & & & \\
Gas saturation & $0.440 / 0.545$ & $0.563 / 0.744$ & $0.647 / 0.737$ \\
Oil saturation & $0 / 0$ & $0.626 / 0.326$ & $0.700 / 0.643$ \\
\hline
\end{tabular}

Area 2 employs a massive modular enclosed system for limitation of gas breakthrough and oil immersion into gas-saturated intervals. High injected amount into the wells of external barrier sequence uncovering oil-saturated reserves of $\mathrm{AB}_{2-3}$ horizon by $70 \%$, as well as unsteady gas extraction from gas wells shifted the pressure balance between the oil and gas parts of the reservoir, resulting in oil and water displacement into the gas part. Replacement of gas by water and oil in non-perforated horizons $\mathrm{AB}_{1}{ }^{3}$ and $\mathrm{AB}_{1}{ }^{1-2}$ had been already observed in the initial period of waterflooding. This phenomenon is mostly manifest in the areas adjacent to the barrier sequence wells.

Table 2

Key development indicators

\begin{tabular}{|c|c|c|}
\hline Indicator & Area 1 & Area 2 \\
\hline Well density, ha/well & 11.3 & 12.5 \\
\hline Production/injection wells ratio & $1: 1$ & $3: 1$ \\
\hline $\begin{array}{l}\text { Oil thickness penetration degree, } \% \\
\text { in wells: } \\
\text { production } \\
\text { injection }\end{array}$ & $\begin{array}{l}51 \\
70\end{array}$ & $\begin{array}{l}60 \\
80\end{array}$ \\
\hline $\begin{array}{l}\text { Gas thickness penetration degree, } \% \\
\text { in wells: } \\
\text { production } \\
\text { injection }\end{array}$ & $\begin{array}{l}70 \\
90 \\
\end{array}$ & $\begin{array}{l}49 \\
60 \\
\end{array}$ \\
\hline $\begin{array}{l}\text { Initial recoverable reserves (IRR) of } \\
\text { oil, million }\end{array}$ & 10.4 & 16.4 \\
\hline $\begin{array}{l}\text { Oil recovery factor }(\mathrm{ORF}) \text { : } \\
\text { approved } \\
\text { current } \\
\text { estimated }\end{array}$ & $\begin{array}{l}0.480 \\
0.360 \\
0.451\end{array}$ & $\begin{array}{l}0.480 \\
0.430 \\
0.482\end{array}$ \\
\hline $\begin{array}{l}\text { Oil production per one well, thousand } \\
\text { tons }\end{array}$ & 47 & 68 \\
\hline $\begin{array}{l}\text { Initial geological reserves (IGR) } \\
\text { of natural gas, billion } \mathrm{m}^{3}\end{array}$ & 8.5 & 20.6 \\
\hline Production, \% IGR & 47 & 27 \\
\hline $\begin{array}{l}\text { Natural gas production, thousand } \\
\mathrm{m}^{3} / \mathrm{t} \text { oil }\end{array}$ & 558 & 415 \\
\hline $\begin{array}{l}\text { Mean (reduced) production, } t / \text { day: } \\
\text { oil } \\
\text { fluid }\end{array}$ & $\begin{array}{c}25.5 \\
220.5\end{array}$ & $\begin{array}{c}23.8 \\
132.4\end{array}$ \\
\hline $\begin{array}{l}\text { Ratio between initial and current pore } \\
\text { pressure * }\end{array}$ & $164 / 184$ & $164 / 164$ \\
\hline Accumulation compensation, $\%$ & 167 & 110 \\
\hline Cumulative water-oil factor (WOF) & 8 & 5 \\
\hline $\begin{array}{l}\text { Oil ingress (per pulsed neutron } \\
\text { logging), year }\end{array}$ & 1981 & 1989 \\
\hline Displaced volume in gas cap, $\%$ & 63 & 41 \\
\hline
\end{tabular}

Note: * - slash separates values for two horizons.

In area 2, along with barrier sequences, dispersed waterflooding system reinforced by focal injection wells is implemented. It ensured a significant improvement in oil production rate versus gas production rate. Overcompensation of production by injection increased water content in the producing wells, causing oil and water influx in the gas cap. Oil migration across the gas-saturated part of the overlying deposits was detected by well logging methods 8 years later than in the area 1 horizons. The main areas of water and oil influx are located 
in the areas adjacent to the inner barrier sequence wells in the absence of a continuous clay partition at GOC.

Development of oil part of both areas implied gas production from the gas cap and injected water production, whereby the gas factor in the initial development stage of area 1 equal to $700-400 \mathrm{~m}^{3} / \mathrm{t}$ exceeded this value obtained for area 2 in the same development period by $1.5-2.0$ times.

The cumulative water-oil factor (WOF) for area 1 is higher than for area 2 (see Table 2). At similar geological features, the implemented development system for area 2, balanced operation modes of production and injection wells have provided for a more efficient recovery. The volume of initially gas-saturated formation displaced by oil and water, according to the comprehensive assessment, totals in $41 \%$ for area 2 and $63 \%$ for area 1 . Comparison of a massive under gas-cap zone development results in Samotlor field areas with different waterflooding patterns has shown that modular development system implementation using focal selective waterflooding is more effective and ensures comparatively high oil production rates with reduced gas breakthrough volumes.

For all development targets, development systems were implemented to varying degrees. Target $\mathrm{AB}_{1}{ }^{1-2}$ employs a dispersed 7-point inverse system with two barrier sequences in the delta front area. In the rest of the "Ryabchik" territory, an outer barrier sequence is formed. For horizon $\mathrm{AB}_{1}{ }^{3}$ in gas-oil part of the reserve, next to the internal GOC, circular waterflooding system is implemented. Target $\mathrm{AB}_{2-3}$ employs a circular waterflooding system consisting of outer and inner barrier sequences in the gas-oil area. Individual sections of GOC use dispersed 7-point system. Gas-oil area of horizon $\mathrm{AB}_{4-5}$ uses a modular waterflooding system.

Overall for $\mathrm{AB}_{1-5}$ horizons three circular systems are formed: at the inner $\mathrm{GOC}-\mathrm{AB}_{1}{ }^{3}$, inner and outer $\mathrm{GOC}-\mathrm{AB}_{2-3}$. Width of areas between the rings varies from 1.3 to $6.5 \mathrm{~km}$.

Gas and gas-oil zones of $\mathrm{AB}_{2-3}$ horizon host 185 wells (outer sequence - 115, inner sequence 70). A massive under gas-cap zone allowed implementing a dispersed system of treatment including separate development modules, which ensured sufficiently effective oil displacement. The received oil production rates from under the gas cap in the basic development period exceeded the breakthrough gas production rate from the gas cap.

After 2003 a process of well conversion from the system of barrier waterflooding had started. Current compensation has stabilized at the level of 90-100\%, water content in production wells remains high. Currently gas production from the gas cap of the reservoir constitutes approximately $70 \%$; combined production of oil and gas by the well stock continues. Barrier sequences of the formation are mostly decommissioned, dispersed injection systems are being optimized to displace the residual volumes of oil from under the gas cap. The development product has high water content; gas factor depends on the distribution of the current reserve structure across the reservoir area and constitutes $150-420 \mathrm{~m}^{3} / \mathrm{t}$. Currently due to the development system implementation using barrier waterflooding at the main highly productive horizon $\mathrm{AB}_{2-3}$ nearly $80 \%$ of gas-saturated thickness is displaced by water and oil. The current structure of reserves is most of all caused by the unstable gas production and horizon waterflooding.

Nevertheless, barrier waterflooding arrangement, in tandem with a massive dispersed system allowed increasing the gas and oil reservoir zone efficiency. Oil production from under the gas cap amounted to $72 \%$ of the initial recoverable reserves (IRR).

In horizon $\mathrm{AB}_{1-3}$, where barrier sequence consists of 137 wells located perimeter-wise between the inner gas bearing contours, narrow under gas-cap zone (from 3.5 to $0.6 \mathrm{~km}$ ) impedes creation of an efficient dispersed injection system, similar to horizon $\mathrm{AB}_{2-3}$. Out of all the 268 wells of the horizon that took part in the gas production from gas cap, only in $40(15 \%)$ only gas production was performed (with gas lift purpose), while in the rest of them liquid fluids and gas were production jointly.

Gas factor of oil producing wells in the basic development period remained high (1800$3500 \mathrm{~m}^{3} / \mathrm{t}$ ), signifying the presence of constant gas flow from the gas cap to oil-saturated part of the horizon in a number of complexly structured areas, despite the growing water injection volume into the barrier wells. Breakthrough gas historical production rates were high. Current gas production from gas cap amounts to $63 \%$ of IGR, oil - $54 \%$ IRR. In the course of barrier waterflooding 
implementation in the horizon $\mathrm{AB}_{1-3}$ the combination of production and injection wells became 1:2, which resulted in a significant overcompensation, gas displacement, oil and water ingress in the gas cap, replacement of $74 \%$ gassaturated thickness. In the present time, the structure of gas reserves in the horizon is mainly determined by waterflooding, as well as active development of the lower productive stratum $\mathrm{AB}_{2-3}$, interlayer water and oil migration.

In this regard, it might be reasonable to conduct a research of oil reserves recovery from reservoirs of clay interlayers in the course of development of the horizon by vertical wells. To this end, hydrodynamic model is used [5]. Let us assume that at the model input (injection well) pressure $1.5 p_{0}$ and water saturation $S w=1$ are given. At the model output (production well) pressure $0.5 p_{0}$, where $p_{0}$ - initial pore pressure. The rest of the conditions and parameters of the task repeat the conditions considered in the research by I.I. Vladimirov, E.V. Zadorozhnyi [6]. Dependence of clay interlayers permeability on the injected water content in the reservoir is exponential $f(S s)=\exp \left(-d \cdot\left(S-S_{0}\right)\right)$, where $d-$ parameter characterizing intensity of well permeability decrease; $S$ and $S_{0}-$ current and initial water saturation values of the reservoir.

Figure 1, $a-c$ presents the dynamics of pressure fields and water saturation for options with various values of clay interlayers permeability decrease indicator: option $1-d=0.0$; option $2-d=10.0$; option $3-d=20.0$.

Obviously, water injection per option $1(d=0)$, where reservoir permeability change does not occur, results in frontal displacement of oil by water, which is concordant with common ideas of oil displacement from a homogeneous reservoir.

Clay interlayers permeability variation in the course of waterflooding by fresh water significantly affects the displacement front. Due to the selective permeability decrease, the residual oil reserves are concentrated in clay interlayers. The higher parameter $d$ is, the more unextracted oil remains in these interlayers (see Figure $1, b, c$ ).

Certain studies $[7,8]$ explore the influence of horizontal wells (HW) and vertical wells (VW) on the nature of waterflooding of a layered horizon with clay interlayers. The results of HW and VW application in the course of reserves recovery are ambiguous.
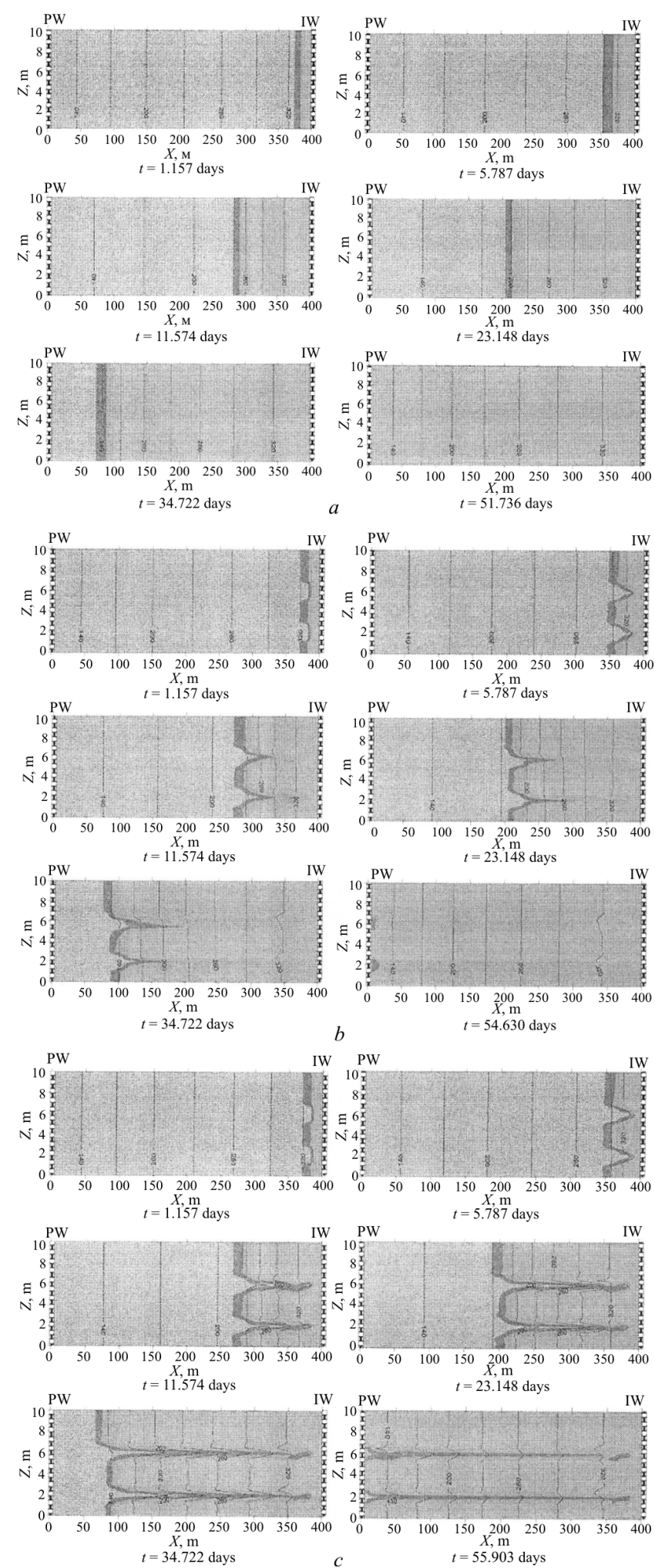

Figure 1. Pressure fields dynamics (isolines) and water saturation (color) for a homogeneous horizon with clay interlayers in the course of development by vertical wells: $a-d=0.0 ; b-d=20.0 ; c-d=10.0$. $Z, \mathrm{~m}$ - depth; $X, \mathrm{~m}$ - width; $t$ - time after well startup;

$\mathrm{PW}$ - production well, IW - injection well 
Comparing the oil production ratio in the course of HW or VW well development using a simple 2D-model it is fair only to discuss nature of waterflooding or oil reserves recovery across the horizon section. If permeability of clay interlayers does not decrease, than the final ORF for 2D model of the reservoir insignificantly depends on the type of the applied well and HW shaft position in the reservoir thickness. If parameter $d$ increases, the efficiency of waterflooding across the horizon section significantly decreases for a vertical well and less so - for a horizontal well. The most efficient option of injection horizontal well shaft location is at the horizon base (option 1 of study [7]). However, with further increase of parameter $d$ part of the oil reserves are cut off due to the decrease of clay interlayers permeability and disruption of hydrodynamic connection between the oil saturated layers. In these conditions the efficiency of HW falls dramatically and it becomes more reasonable to use VW that enable extraction of oil from all sand interlayers isolated from one another by clay interlayers that have become impenetrable.

E.V. Zadorozhnyi [9] performed improvement of oil residual reserves recovery technology from inhomogeneous layers of clay-containing $\mathrm{AB}_{1}{ }^{1-2}$ horizon reservoirs in Samotlor field based on theoretical research and subsequent trials in the production sites. In cooperation with I.V. Vladimirov, N.I. Khisamutdinov et al. [10] he established that the procedure of vertical and horizontal well performance indicators comparison for this purpose requires correction.

The performed analysis established the following:

1. The scheme of barrier sequences installation and operation implemented in Samotlor field to a large extent facilitated mitigation of gas breakthroughs and stabilization of gas factor. However, $80 \%$ of gas from the gas cap was production by the well stock from under the gas cap.

2. The main disadvantages of the implemented development schemes for $\mathrm{AB}_{1-3}$ horizons using barrier waterflooding are partial involvement of narrow under-gas areas in oil recovery, high water content in the product at early stages of development, production of massive volumes of breakthrough gas, waterflooding of gas-saturated formations.
3. Gas reserves localization zones in the gas cap of unreplaced volume of gas-saturated thickness are $50 \%$ by integrated estimation and have complex geometry.

4. Organization of dispersed and focal selective waterflooding in combination with barrier sequences formation in $\mathrm{AB}_{2-3}$ horizon facilitated the development efficiency increase, but not entirely due to consistently high water content of the producing wells. Operation of inner barrier sequence of $\mathrm{AB}_{2-3}$ horizon caused gas displacement to the oil part of the reservoir, which complicated the formation development.

5. In the course of development of layered inhomogeneous reservoirs with anisotropic permeability field, efficiency of the development system using wells that uncover all oil-saturated interlayers of the horizon depends on the extent of hydrodynamic connection. It is necessary to research the dependence between efficiency of oil and gas reservoir waterflooding and field wells profile.

\section{Impact of geological and physical properties of $A B$ group horizons on oil reserves recovery in Samotlor gas field}

Russian researchers have been studying the relation between efficiency of development of multifacies terrigenous reservoirs and their particle size distribution (macroinhomogeneity) and orientation of sandstones grain mass in the interlayers (microinhomogeneity). As a result of research of the influence of sediment accumulation conditions on the production conditions at the reservoir and performance of the wells conducted by S.B. Denisov, G.M. Zoloeva, I.V. Evdokimov, R.M. Kuramshin, R.H. Muslimov, S.V. Nikiforov et al., it was established that:

- sand package geometry can be justified based on sedimentation conditions analysis;

- initial porosity and permeability value is defined by sedimentation processes;

- final distribution of porosity and permeability is justified by diagenesis processes;

- presence of linear sand bodies can cause high lateral anisotropy of rock properties, with axes of anisotropy of improved porosity and permeability directed along the lines of filtration flows.

These conclusions should be taken into account when designing waterflooding, reservoir pressure maintenance systems (RPM) and enhanced oil recovery methods. 
It is well known that macrolevel inhomogeneity (grittiness, compartmentalization) plays a defining role in formation of prevailing directions of reservoir fluids filtration flows. Microlevel inhomogeneity (anisotropy, lateral permeability variability) influences the nature of mass exchanging processes, target fluid displacement indicators and phase permeability variation.

In the research conducted by R.G. Sarvaretdinov et al. [11, 12] six lithotypes of rock were identified in each of the 5 interlayers of $\mathrm{AB}_{1}{ }^{1-2}$ horizon structure. The research of reservoir fluids filtration mechanisms has shown that the proportion of fluid inflow to each of the interlayers varies significantly. This can be explained by the type of reservoir structure, varying porosity and permeability and interlayers thickness.

Based on the representations by A.V. Khabarov et al., J.O. Amaefile et al. [13, 14], lithological classification of rocks in the studied sequence allows segregating individual groups of rocks that deposited in similar sedimentation conditions and were exposed to similar diagenetic metamorphoses. The results of research are instrumental in attributing the unique permeability correlations $\left(k_{\text {per }}\right)$ and porosity correlations $\left(K_{\text {por }}\right)$ to the groups, as well as capillary pressure profiles and shapes of phase permeability curves.

In the process of analysis of particle size distribution, pore measurement data, results of designated core samples research in cooperation with A.V. Khabarov and other specialists of "Tyumen oil research center" LLC, 3 types of reservoirs were determined: 1) the most highly permeable (homogeneous large pore sandstone); 2) standard; 3) variations with high clay content (both disperse and layered).

For determining the fluid content and oil and gas saturation factor $\left(K_{\mathrm{og}}\right)$, a comprehensive method by Ya.E. Volokitin and A.V. Khabarov and capillary saturation model [15] where used to augment and verify the electrical model. Adequacy of electrical model is confirmed by high reproducibility of results against data received with the aid of capillary model.

It has been established that electrical resistance of layered rock is an anisotropic parameter. As a rule, the vertical resistance is higher than horizontal resistance along the layers, i.e. in the same horizon the horizontal well resistance will be higher than in the vertical well. Failure to take into account this phenomenon results in inadequately high calculated values of $K_{\mathrm{og}}$ in horizontal wells.

Based on the comparison of specific electrical resistance values (SER) of rocks in pilot subvertical and main subhorizontal wellbores, SER of horizontal wells is 1.3-1.5 times higher than that of the subvertical ones. The received correlation allows correcting SER value taking into account the electrical anisotropy of rocks and, as a result, verify $K_{\text {og }}$ in the wells with outstandingly high values of vertical deviation.

It is well known that in order to estimate permeability, it is crucial to take into account lithological properties and pore space structure. In the absence of fractured and cavernous rock, there must be a correlation between porosity/permeability based on geophysical and hydrodynamic research, and actual wells productivity.

The obtained permeability model demonstrated a distinct correlation with hydrodynamic logging (HDL) data (Figure 2) and allows identifying highly permeable interlayers in the nonhomogeneous reservoirs interval.

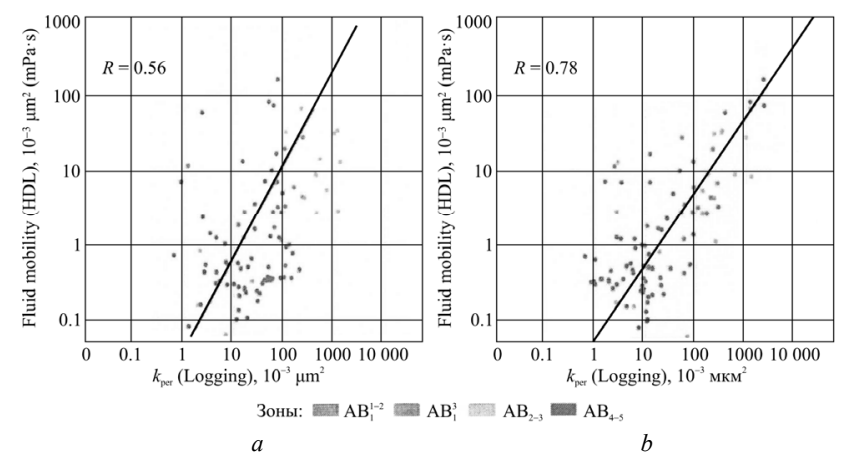

Figure 2. Comparison of fluid mobility by logging data and fluid mobility by HDL data for the old $(a)$ and new $(b)$ model

Facies analysis has established that during formation of $\mathrm{AB}_{4-5}$ horizon deposits there was an intense ingress of fragmentary material with a high proportion of sand fraction. Sedimentation process was accompanied by activation of tectonic processes; against their background, delta front and delta deposits prograded from south-east to northwest. Sand bodies are represented by such facies as delta front (amalgamated sandstones), deltoid channels and stream-mouth bars. Since the ingress 
of sandy material was abundant, hydrodynamic connection in lateral direction is pervasive. Vertically, the hydrodynamic connection is less seamless due to the presence of focal clay interlayers. Sedimentation activity significantly decreased by the end of $\mathrm{AB}_{4-5}$ horizon formation period, during which an extensive delta plain was developed in the territory, crossed by rare but powerful, most probably subaerial, deltoid channels.

$\mathrm{AB}_{2-3}$ horizon deposits are related with intensive sediment accumulation in conditions of delta plain where deposits consist of facies of shoestring sandy delta channels and bars, as well as facies of thin-layer structures occurring between the shoestring bodies. Sand content in the sequence is relatively high; therefore, vertical and horizontal continuity is present, though with varying degrees of seamlessness.

$\mathrm{AB}_{1}{ }^{3}$ horizon deposits consist of intermediate facies that were formed during immersion of the sea basin, decrease of sand fractions share in the incoming fragmentary material, activation of tectonic displacement that formed the drag folds of the north-west stretch.

The processes of sea basin immersion and tectonic displacement most of all impacted the formation of $\mathrm{AB}_{1}{ }^{1-2}$ horizon deposits. Argillaceous sandstones of this area are represented by facies of blanket deposits. Massive sand bodies in the east of the field were formed at the final stage of $\mathrm{AB}_{1}{ }^{1-2}$ horizon formation as a result of avalanche-type sedimentation.

Due to the tectonic sedimentation processes, an integrated hydrodynamic system has formed for horizons $\mathrm{AB}_{1-5}$, with one WOC and one GOC. The reservoir's integrity is ensured by low thickness or even absence of clay interlayers between the horizons. Presence of a gas cap was confirmed by multiple production data and geophysical materials based on which the GOC can with a high degree of confidence be established on the elevation mark of $1611 \mathrm{~m}$. Group AB productive strata are characterized by an extremely complex facies environment of development, which occurred predominantly in coastal-marine conditions, areas of semi-closed sea gulfs and lagoons, deltoid paleoriver carry-overs. These conditions influenced both the nature of various deposits distribution and their structure, causing the existing inhomogeneity of productive strata rocks reservoir properties. AB horizons sand bodies were formed in conditions of shallow sea with abundant ingress of fragmentary material. Actually Samotlor field area in that period was an extensive delta-front flatland with facies of deltoid channels, streammouth bars with shoestring sand bodies and facies of interchannel fillers consisting of inhomogeneous alternations of sandstones, aleurolites, mudstones, and clays.

In the course of $\mathrm{AB}_{1}{ }^{1-2}$ horizon productive section analysis as the most lithologically variable in Samotlor field, special attention was paid to the textural features (consolidation and compartmentalization) of reservoirs. As a result, the horizon reservoirs were classified into three groups: with massive texture (MT), with thin-layer texture (TLT), and mixed texture (MT + TLT). Thus, for all of the studies horizons, three types of sections were defined (Figure 3, exemplified by horizon $\mathrm{AB}_{1}{ }^{1-2}$ ):

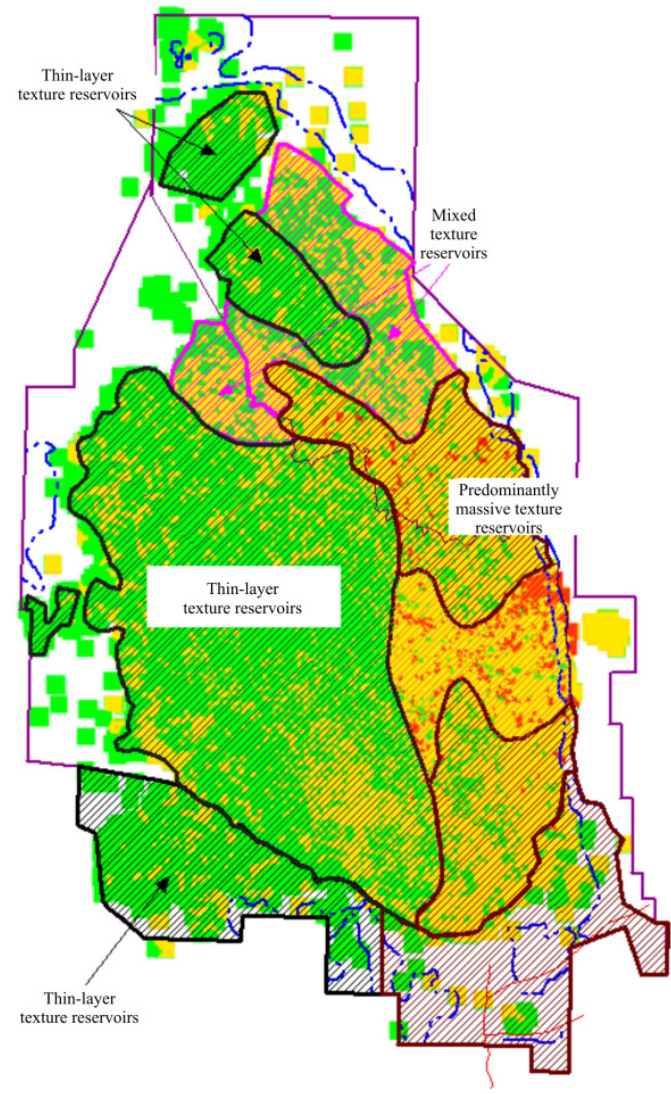

Figure 3. Schematic borders of various textures in horizon $\mathrm{AB}_{1}^{1-2}$

- Structure type I - composed of reservoirs with massive texture (MT);

- Structure type II - composed of reservoirs with thin-layer texture (TLT); 
- Structure type III - mixed, where the horizon consists of reservoirs with different texture (MT + TLT).

Drawing on the detailed study of geological and physical structural properties and the results of facies analysis, criteria of categorization were determined for each of the horizons (Table 3, exemplified by horizon $\mathrm{AB}_{1}{ }^{3}$ ).

Table 3

Porosity and permeability of reservoirs per $\mathrm{AB}_{1}^{3}$ horizon structural types

\begin{tabular}{|l|c|c|c|}
\hline \multicolumn{1}{|c|}{ Parameter } & MT & TCT & MT + TCT \\
\hline Porosity factor, fraction unit & 0.27 & 0.25 & 0.26 \\
\hline Permeability factor, mD & 319.5 & 110.28 & 310.72 \\
\hline Oil saturation, fraction unit & 0.66 & 0.56 & 0.62 \\
\hline
\end{tabular}

\section{Geological and hydrodynamic target model improvement}

In 2007-2008, in order to manage the field development, a geological-hydrodynamic model for $\mathrm{AB}_{1-5}$ horizons group was created. Problems of target area modeling caused by the structural features of the horizons, its size $(50 \times 80 \mathrm{~km})$, development duration and a high amount of wells are described in [16]. However, during the study of combined development of the gas cap and oil rim it was identified that in the course of model adaptation to the development history the volume of unproductive injection was estimated at 15-20\% (material balance method), whereby a decision was made not to reproduce the injection in the model in its full scope. Gas cap pressure level is assumed to be by $1.0-1.5 \mathrm{MPa}$ lower than actual (it is a significant level of uncertainty for the gas cap in the course of assessment of gas production and volume of fluid invading the gas cap). The oil and gas carbohydrate deposits in West Siberian oil and gas province are known to have a high content of relict (residual) oil in the gas-saturated part of horizons. N.N. Mikhailov research school [17-19] established that the reserves of residual oil are a complex dynamic structure consisting of several individual varieties with their distinct properties and degree of mobility. It has been shown that a significant residual oil distribution inhomogeneity forms in the inter-well space. The applied systems for deployment and well density significantly influence the displacement factor. Waterflooding of the horizons allows displacing residual oil, but the degree of displacement depends on the correlation between reservoir properties of the intervals represented by rocks with distinct variability.

Residual gas saturation structure in the course of gas displacement with water or oil approximates the structure of residual oil saturation. This is confirmed by comparative experimental studies with oil and gas displacement by water, e.g. those in the research of M.W. Legatski [20]. The difference is that in the initially gas-saturated reservoir the hydrophobic parts of the pore surface are mostly wetted with gas (excluding the parts wetted by relict oil). In the event of oil ingress in the gas-saturated reservoir, residual oil saturation is determined only by capillary entrapped oil, since gas in reservoir conditions is more hydrophobiainducing than oil, so oil wetting of surface is unlikely.

In the course of 2008 model adaptation, a simulation was performed based on the example of $\mathrm{AB}_{1}{ }^{1-2}$ horizon. It was established that the input assumptions of the vertical reservoir coherence adopted in the model (for horizon $\mathrm{AB}_{1}{ }^{1-2}$ the relation between vertical and horizontal permeability is set as $1 / 1000$, for the rest $-1 / 100$ ) did not reflect the real flow distribution between the horizons. For a more adequate modeling of vertical coherence it was decided to recalculate the vertical permeability of enlarged cells (vertical size $-2.6-10.0 \mathrm{~m}$ ) accounting for the presence of clay interlayers in them. To set the residual oiland gas saturation, their values were correlated with initial saturation of the reservoir by oil or gas. As a rule, to determine the residual oil saturation, correlation between its values and reservoir permeability is used; however it is applicable only for peak saturation, and its use for transition area considerably underestimates mobile oil reserves. Russian researchers [21] have established that residual oil saturation is primarily determined by the initial saturation of the reservoir. This is confirmed by an isolated core research (Figure 4).

After processing the data obtained by S.V. Dvorak et al. [22] as well as our own experimental data for Samotlor field, we were able to show that reservoir oil saturation above the GOC should be defined taking into account the distance to the GOC, $\alpha_{\mathrm{sp}}$ values and relict oil saturation.

Residual oil and water saturation were determined separately for horizon $\mathrm{AB}_{t}{ }^{1-2}$ and other horizons. Residual oil saturation in the oil reservoir 


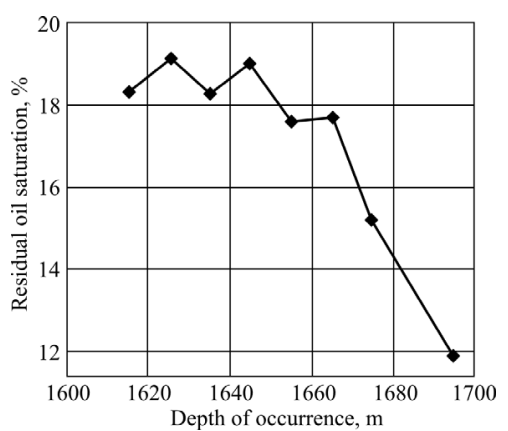

Figure 4. Dependence of residual oil saturation (determined by the sealed core sample) from true vertical depth for horizons $\mathrm{AB}_{1-5}$ of Samotlor field (porosity is 24-28\%, true vertical depth of gas-oil contact - $1611 \mathrm{~m})$

was determined based on displacement factor $\left(K_{\mathrm{dis}}\right)$, defined for each reservoir class by correlations obtained from processing of experimental data,

$$
K_{\text {dis }}=\left(1+\frac{1}{\alpha+\beta k_{\text {per }}}\right)^{-1},
$$

where $\alpha, \beta-$ factors $[21] ; k_{\text {per }}-$ permeability factor.

In order to determine phase permeability values for gas, oil and water at critical saturation values correlations with reservoir permeability and porosity were used (based on the theoretical regularities defined by Iu.E. Baturina, N.Ia. Medvedeva et al. [23]), received by way of processing of experimental relative phase permeability values. To account for the vertical inhomogeneity of $\mathrm{AB}_{1-5}$ horizons group in the model, a method of vertical permeability cube construction was used, based on parameters of the initial geological model.

Thus, drawing on the aforementioned provisions, the model was amended as follows:

1. In $\mathrm{AB}_{1-5}$ horizons saturation model, based on the results of drill samples examination, geophysical and literary data, the initial (relict) oil saturation of gas cap was introduces depending on the height above the gas-oil contact and porosity (mean saturation amounted to $5 \%$ ).

2. Residual oil saturation of gas cap depending on porosity, initial oil and gas saturation was set at the level by 3-5\% higher than relict oil saturation (based on the research of conditions of residual oil saturation formation in polymictic reservoirs of the West Siberia).
3. Residual gas saturation of the gas cap as a function of porosity and permeability, as well as initial gas saturation of the reservoir (based on core samples examination and data provided in literary sources) is assumed as equal to $23-29 \%$.

4. Residual oil saturation in initially oilsaturated area of the horizons is set depending on the porosity, permeability and initial oil saturation (based on the research of residual oil saturation formation conditions in polymictic reservoirs of the West Siberia).

5. Based on the laboratory research results and literary data, correlations were received for dependency of end points of phase permeability values on porosity and permeability of reservoirs with subsequent scaling of phase curves in each active cell of the model.

6. Vertical permeability cube calculated based on geological model data with use of anisotropy factor dependence on self-potential method indicator $\alpha_{\mathrm{sp}}$ was introduced in the hydrodynamic model.

Increase of physical informative potential of the model improved adaptation quality in terms of the main process parameters of development and reliability of oil and gas production forecasting. As a result of the amendments, it became possible to reproduce the current reservoir pressure distribution in the gas cap volume, and to eliminate discrepancy between actual and calculated injection data.

\section{Waterflooding technology trial after adaptation to the determined specific geological and physical features}

To assess the efficiency of barrier waterflooding with the use of hydrodynamic model of $\mathrm{AB}_{1-5}$ horizons group, a version of $\mathrm{AB}_{1-5}$ horizons group development was calculated as if it were absent in the historic period. The calculation results were compared to the basic version concordant to the history of $\mathrm{AB}$ horizons development reproduced in the model.

Each of the $\mathrm{AB}_{1-5}$ horizons group is officially considered an independent target of development, but in fact there is a connection between the horizons conditioned by several geological reasons and man-induced factors.

Comparison of calculation results for the basic version and version without barrier waterflooding was performed for each of the horizons and for $\mathrm{AB}_{1-5}$ group as a whole. The main calculation 
indicators for the comparison were oil and free gas production indicators dynamics, fluid volumes migrating through GOC in the process of development: oil and water ingress in the gas cap, current gas reserves in the gas cap.

Overall the arrangement of barrier waterflooding facilitated the reduction of breakthrough gas volumes from gas cap to the production wells and, to a certain extent, prevented the oil from entering the gas caps, however this process was not completely overcome and in subsequent years there were sporadic migrations of oil into gas caps and ingress of free gas into the oil part.

Comparison of accumulated volumes dynamics for oil and water ingress in the gas cap for individual horizons and $\mathrm{AB}_{1-5}$ group in general, for free gas ingress in the oil are, in case of presence and absence of barrier waterflooding based on results of hydrodynamic modeling is presented in Figure 5.

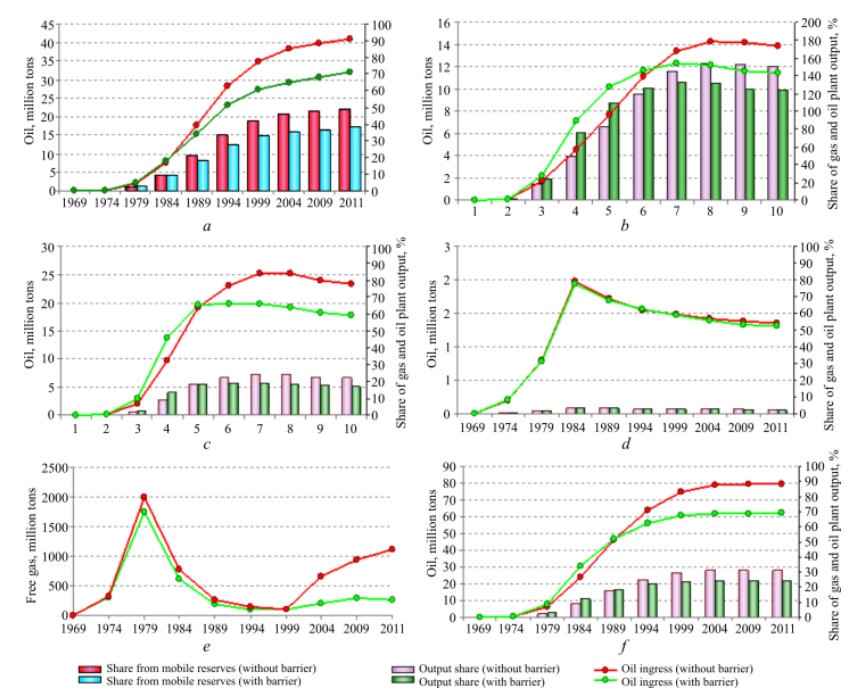

Figure 5. Dynamics of accumulated ingress volumes of oil into the gas cap and free gas into the oil zone: $a$ - oil ingress into the gas cap, horizon $\mathrm{AB}_{1}{ }^{1-2} ; b$ - oil ingress into the gas cap, horizon $\mathrm{AB}_{1}{ }^{3} ; c-$ oil ingress into the gas cap, horizon $\mathrm{AB}_{2-3} ; d$ - oil ingress into the gas cap, horizon $\mathrm{AB}_{4-5} ; e$ - free gas volume below GOC, million $\mathrm{m}^{3}$; $f$-oil ingress into the gas cap, horizon $\mathrm{AB}_{1-5}$

Based on the accumulated volumes of free gas ingress in the oil part of the reservoirs, a difference was identified between the versions received in the period of 2000-2010, when due to the active commissioning into development of producing wells of the gas and oil area, production of fluid and oil was increased. It was established that the reason of gas migration increase in the version without barrier waterflooding was the presence of horizon junction windows, resulting in the ingress of massive free gas volumes into the oil are of the reservoir. As of the date of assessment, the ingress volume of free gas under the version without barrier waterflooding amounted to 1.1 billion $\mathrm{m}^{3}$, which is 5 times more than in the version with use of barrier waterflooding $\left(0.26\right.$ billion $\left.\mathrm{m}^{3}\right)$.

The accumulated volumes of water ingress in the gas cap were assessed as 328.4 million $\mathrm{m}^{3}$. This is $22 \%$ more than in the version without barrier waterflooding in the historic period (269.5 million $\mathrm{m}^{3}$ ), which constitutes 15.2 and $12.5 \%$ respectively from the pore volume of the gas bearing part of $\mathrm{AB}_{1-5}$ horizons group.

Barrier sequences arrangement in horizons $\mathrm{AB}_{1}{ }^{1-2}, \mathrm{AB}_{1}{ }^{3}$ and $\mathrm{AB}_{2-3}$ according to the calculations allowed reducing the volumes of oil ingress into the gas caps by 17 million tons (or by $27 \%$ ).

Implementation of barrier waterflooding also facilitated the migration of massive water volumes into the gas cap. Significant water injection volumes into the barrier wells promoted water breakthrough to the production wells of the gas and oil area adjacent to the barrier sequences from the outer side, and their quick waterflooding. Injection of high volumes of water in the barrier wells of $\mathrm{AB}_{2-3}$ horizon caused significant migration of fluids between the targets, and first of all the fluid migration from $\mathrm{AB}_{2-3}$ target into the gas part of $\mathrm{AB}_{1}{ }^{3}$ through the large junction windows. The inner barrier sequence of $\mathrm{AB}_{2-3}$ horizon was proposed to be decommissioned.

Therefore in under-the-cap area of $\mathrm{AB}_{1}{ }^{3}$ horizon, taking into account the existing gas reserves structure, presence of displaced volume of the gas cap ad minor residual gas reserves localization areas, barrier waterflooding is not necessary. In this area it is required to improve efficiency of dispersed and focal selective development systems, along with purely oil area of the reservoir. Moreover, gas production has to be arranged in the local areas using the gas stock wells together with $\mathrm{AB}_{1}{ }^{1-2}$ horizon where the main reserves of gas are concentrated.

In this context, a research was conducted in cooperation with K.M. Fedorov on the operation of horizontal wells with low-angle and sinusoidal wellbore profile, which are known to be less dependent on the vertical inflow component and allow increasing the vertical drainage area [24]. 
A comparative analysis was performed for the well productivity with horizontal, low angle and sinusoidal wellbore profile using sectoral geological and hydrodynamic model of $\mathrm{AB}_{1}{ }^{1-2}$ horizon consisting of three equally thick interlayers $(2.5 \mathrm{~m}$ each) with different horizontal permeability factor value $(8 ; 12 ; 17 \mathrm{mD})$. Intervals of low angle and sinusoidal part are replaced with sectional horizontal parts uncovering the horizon. Horizontal wellbore length is $L=500 \mathrm{~m}$, pressure sink - $10 \mathrm{MPa}$. Let us assume that one can neglect the motional friction of formation fluid in the wellbore.

To solve this task, it is required to know the drainage radius of the well. A common method for horizontal well drainage area calculation [25] is considering it as a total of the areas of two halves of the circle with radius $b$ and area of rectangle $2 b L$. Let us assume that radius $b$ is equal to drainage radius of vertical well $r_{\mathrm{B}}$, and drainage area can be expressed as

$$
S=\pi r_{\mathrm{B}}^{2}+2 L r_{\mathrm{B}} .
$$

As a rule, $r_{\mathrm{B}}$ is assumed to be a semi-distance between the wells which for this sector of horizon $\mathrm{AB}_{1}{ }^{1-2}$ constitutes $300 \mathrm{~m}$. Therefore, it is possible to calculate drainage area for each separate segment of the low angle or sinusoidal well taking into account the length of horizontal wellbores in this interlayer.

Based on the calculation results it was established that the value of the low-angle well production output exceeds the horizontal well production output by 2.2 times, while the sinusoidal profile well production output exceeds the low-angle well production output by 1.4 times.

To verify the estimations, calculations were performed in the sector model of $\mathrm{AB}_{1}{ }^{1-2}$ horizon with application of three-phase hydrodynamic model of the area, constructed with Eclipse simulator. To take into account possible degassing of oil in the wellbore area, gas phase was introduced into the model. Forecast calculations were performed for the period of 15 years ahead, on condition that bottom-hole pressure will remain the same during the entire time of operation and will be equal to $6 \mathrm{MPa}$. Skin factor was assumed as zero. Wellbore length of nominally horizontal part was $500 \mathrm{~m}$. Horizontal, low-angle and vertical profiles were studied. In all options, the wellbore was located in the upper half of $\mathrm{AB}_{1}{ }^{1-2}$ horizon, since its base part is less oil saturated.

It was established that the horizontal part of the well was the least efficient. The cumulative oil production amounted to 41.2 thousand tons at cumulative fluid production of 176.6 thousand tons. Cumulative oil production in a well with low angle wellbore profile is higher than that of the well with a horizontal profile by $40 \%$. Sinusoidal bore profile is the most efficient one. Cumulative oil production exceeds one for the low angle wellbore profile by $17.8 \%$.

The above mentioned results allowed substantiating the key points in assessment of horizontal drain efficiency. However, all the conclusions relate to a horizon with homogeneous or nominally homogeneous permeability. Research [26] considers an example of zonally inhomogeneous permeability horizon, where RPM system has been formed. The area of reduced permeability is uncovered by the well where a hydraulic fracture is created to induce productivity of the well or a horizontal sidetrack is constructed.

Based on the displacement features application, a conclusion was made that the operation of horizontal wellbores in low permeability area of the horizon distanced from the injection wells sequence is a more attractive option in terms of process efficiency, providing a more impressive oil production rate and lower water production increase.

\section{Summary}

1. Drawing on the analysis of reservoir textural features in each of the studied productive horizons, three types of sequences were determined: reservoirs with massive, thin layer and mixed texture. For these types of reservoirs, identification criteria and distinctive features were established.

2. It was determined that group $A B$ productive horizons have an extremely complicated facies environment of development, which occurred predominantly in coastal-marine conditions, areas of semi-closed sea gulfs and lagoons, deltoid paleoriver carry-overs. These conditions influenced both the nature of various deposits distribution and their structure, causing the considerable inhomogeneity of productive strata rocks reservoir properties. The research results permit to distinguish areas with varying facies attribution within the studied horizons. 
3. It was established that barrier waterflooding has the highest efficiency in delta front areas. An explanation was provided for the influence of facies attribution of a horizon area upon efficiency of barrier waterflooding, related to the distribution of interlayers with different permeability, as well as to the reservoir compartmentalization.

4. Recommendations were developed in view of optimization of the barrier waterflooding technology depending on the facies features of the area.

\section{References}

1. Makarov A.V. Puti vovlecheniia neaktivnykh zapasov Liantorskogo mestorozhdeniia putem sozdaniia nestatsionarnykh rezhimov $\mathrm{v}$ plaste [Ways of involving the inactive reserves Lyantorskoye field through the creation of transient regimes in the reservoir]. Neftepromyslovoe delo, 2000, no.5, pp.5-9.

2. Muslimov R.Kh. Metody povysheniia effektivnosti razrabotki neftianykh mestorozhdenii $\mathrm{v}$ zavershaiushchei (chetvertoi) stadii [Methods to improve the efficiency of oil field development in the final (fourth) stage]. Materialy rasshirennogo zasedaniia TsKR Rosnedr (neftianaia sektsiia), 4-5 dekabria 2007: sbornik dokladov. Moscow: NP NAEN, 2008, pp.20-35.

3. Lisovskii N.N., Shagiev R.G. Polnota informatsii o produktivnom plaste i povyshenie effektivnosti razrabotki [The completeness of the information about the reservoir and increase the efficiency of development]. Materialy rasshirennogo zasedaniia TsKR Rosnedr (neftianaia sektsiia), 4-5 dekabria 2007: sbornik dokladov. Moscow: NP NAEN, 2008, pp.78-89.

4. Lanina O.V., Sokolov S.V., Chusovitin A.A. Sravnenie effektivnosti sistem razrabotki podgazovoi zony Samotlorskogo mestorozhdeniia [Efficiency comparison of under-gas-cap zone development systems at Samotlorskoye field]. Neftianoe khoziaistvo, 2013, no.2, pp.2-4.

5. Vladimirov I.I., Spivak S.I. Matematicheskoe modelirovanie protsessov izvlecheniia nefti pri razrabotke glinosoderzhashchikh kollektorov gorizontal'nymi skvazhinami [Mathematical modeling of oil extraction in the development of clay-containing collectors with horizontal wells]. Materialy 4 nauch.tekhn. konf. molodykh spetsialistov OOO «RN-UfaNIPIneft'», 3-5 marta 2010 g. Ufa, 2010, pp.43-47.

6. Vladimirov I.I., Zadorozhnyi E.V. Matematicheskoe modelirovanie protsessov nefteizvlecheniia pri razrabotke gorizontal'nymi skvazhinami kollektorov $\mathrm{s}$ povyshennym soderzhaniem glinistykh mineralov [Mathematical modeling of oil extraction processes in the development of collectors with horizontal wells with high content of clay minerals]. Avtomatizatsiia, telemekhanizatsiia $i$ sviaz' $v$ neftianoi promyshlennosti, 2011, no.10, pp.45-47.

7. Antonov M.S., Rodionova I.I., Fatkhlislamov M.A., Khisaeva D.A. Zavisimost' effektivnosti neftevytesneniia iz plastov s glinistymi prosloiami ot polozheniia stvola gorizontal'noi nagnetatel'noi skvazhiny [Dependence of efficiency of oil replacement out of formations with clay interlayers on location of horizontal injection bore hole]. Neftepromyslovoe delo, 2012, no.1, pp.53-56.

8. Lazeev A.N., Rodionova I.I., Khisaeva D.A., Shaimardanov M.N. Sopostavlenie pokazatelei vyrabotki zapasov nefti iz plasta pri polnom i chastichnom zatukhanii fil'tratsii $v$ glinistykh prosloiakh [Comparison of showings of oil resources extraction from a layer in case of complete or partial filtration fading in clay inter-layers]. Neftepromyslovoe delo, 2012, no.1, pp.50-53.

9. Zadorozhnyi E.V. Osobennosti razrabotki sloistoneodnorodnykh glinistykh kollektorov plasta $\mathrm{AV}_{1}^{1-2}$ Samotlorskogo mestorozhdeniia [Some peculiarities of development of stratified-heterogeneous clayish collectors of $\mathrm{AB}_{1}^{1-2}$ formation of Samotlor field]. Neftepromyslovoe delo, 2011, no.12, pp.10-14.

10. Vladimirov I.V., Khisamutdinov N.I., Zadorozhnyi E.V., Litvin V.V. Issledovanie effektivnosti razmeshcheniia gorizontal'nykh i vertikal'nykh skvazhin $\mathrm{v}$ zalezhakh sloistogo geologicheskogo stroeniia [Studying of efficiency of horizontal and vertical wells placement in deposits of stratified geological structure]. Oborudovanie $i$ tekhnologii dlia neftegazovogo kompleksa, 2011, no.5, pp.8-12.

11. Shaimardanov M.N. Otsenka vliianiia glinistosti kollektora na KIN pri razrabotke zalezhi sistemoi vertikal'nykh skvazhin [Assessment of a collector's shaliness effect on oil recovery coefficient in case of a deposit development by means of verical wells system]. Avtomatizatsiia, telemekhanika $i$ sviaz' $v$ neftianoi promyshlennosti, 2011, no.11, pp.40-44.

12. Shaimartdanov M.N., Sarvaretdinov R.G., Sagitov D., Vinokhodov M.A., Glebov S.D. Izuchenie protsessa zavodneniia tonkosloistykh mnogosloinykh kollektorov [Studying of water-flooding process of thin-bed multilayer collectors]. Neftepromyslovoe delo, 2013, no.3, pp.86-90.

13. Khabarov A.V., Volokitin Ia.E. Metodika kompleksnogo analiza dannykh kerna i GIS s tsel'iu litologicheskoi klassifikatsii terrigennykh kollektorov [Procedure for combined analysis of core and log data for lithologic classification of terrigenous reservoirs]. Karotazhnik, 2009, vol.189, pp.83-128.

14. Amaefile J.O., Altunbay M., Diebbar T. et al. Enhanced reservoir description: using core and log data to lolentify Hydralic (F-low) Units and predict permeability in uncored intervaig/wells. Society of Petroleum Engineers, 1993, 205.

15. Volokitin Ia.E., Khabarov A.V. Kompleksnaia metodika otsenki koeffitsienta neftenenasyshchennosti geterogennykh kollektorov [Combined technique for heterogeneous reservoir oil saturation evaluation]. Karotazhnik, 2009, vol.189, pp.143-166.

16. Arzhilovskii A.V., Bikbulatova T.G., Kostiuchenko S.V. Opyt modelirovaniia Samotlorskogo mestorozhdeniia: problemy i perspektivy [Samotlorskoye field modeling case history: issues and prospects]. Neftianoe khoziaistvo, 2010, no.11, pp.46-50. 
17. Mikhailov N.N. Ostatochnoe neftenasyshchenie razrabatyvaemykh plastov [Residual oil saturation of developed reservoirs]. Moscow: Nedra, 1992, 270 p.

18. Mikhailov N.N., Kol'chitskaia T.N., Dzhemeson A.V. et al. Fiziko-geologicheskie problemy ostatochnoi neftenasyshchennosti [Physical and geological problems of residual oil saturation]. Moscow: Nedra,1993, 352 p.

19. Mikhailov N.N., Varlamov D.P., Klenkov K.A. Modelirovanie vliianiia sistem rasstanovki skvazhin na ostatochnoe neftenasyshchenie zavodnennykh plastov [Modeling the influence of well placement system on residual oil flooded reservoirs]. Burenie $i$ neft', 2004, no.1, pp.13-15.

20. Legatski M.W., Katz D.L., Tek M.R., Gorring R.L., Nielsen R.L. Displacement of gas from porous media by water. Fall Meeting of the Society of Petroleum Engineers of AIME, 11-14 October 1964. Houston, 1964. DOI: 10.2118/899-MS

21. Cheremisin N.A., Sonich V.P., Baturin E.Iu., Drozdov V.A. Issledovanie uslovii formirovaniia ostatochnoi neftenasyshchennosti V polimiktovykh kollektorakh Zapadnoi Sibiri [Investigation of the residual oil saturation's formation conditions in polymictic reservoirs of Western Siberia]. Neftianoe khoziaistvo, 1997, no.9, pp.40-45.
22. Dvorak S.V., Sonich V.P., Nikolaev E.V. Zakonomernost' izmeneniia neftenasyshchennosti v gazovykh shapkakh Zapadnoi Sibiri [The pattern of changes in oil saturation in gas masks in Western Siberia]. Povyshenie effektivnosti razrabotki neftianykh mestorozhdenii Zapadnoi Sibiri. Tiumen': SibNIINP, 1988, 163 p.

23. Cheremisin N.A., Sonich V.P., Baturin Iu.E., Medvedev N.Ia. Fizicheskie osnovy povysheniia effektivnosti razrabotki granuliarnykh kollektorov [Physical bases of increase of efficiency of development of granule collectors]. Neftianoe khoziaistvo, 2002, no.8, pp.38-41.

24. Brilliant L.S., Klochkov A.A., Vydrin A.G. et al. Tekhnologiia optimizatsii sistemy razrabotki ob"ekta $\mathrm{AV}_{1}^{1-2}$ Samotlorskogo mestorozhdeniia [Reservoir geological properties effect on the effectiveness of horizontal wells drilling at the Samotlorskoye field $A V_{1}^{1-2}$ object]. Neftianoe khoziaistvo, 2010, no.10, pp.82-84.

25. Ahmed T. Reservoir engineering handbook. Huston: Gulf professional publishing, 2000, 1211 p.

26. Vladimirov I.V., Khisamutdinov N.I., Arzhilovskii A.V., Chusovitin A.A., Gnilitskii R.A. Vliianie GRP na vyrabotku neodnorodnogo po pronitsaemosti uchastka plasta [Effect of a formation hydraulic fracturing on oil recovery from a formation sector with heterogeneous permeability]. Neftepromyslovoe delo, 2012, no.1, pp.68-71.

\section{Список литературы}

1. Макаров А.В. Пути вовлечения неактивных запасов Лянторского месторождения путем создания нестационарных режимов в пласте // Нефтепромысловое дело. - 2000. - № 5. - С. 5-9.

2. Муслимов Р.Х. Методы повышения эффективности разработки нефтяных месторождений в завершающей (четвертой) стадии // Материалы расширенного заседания ЦКР Роснедр (нефтяная секция), 4-5 декабря 2007: сб. докладов. - М.: НП НАЭН, 2008. - С. 20-35.

3. Лисовский Н.Н., Шагиев Р.Г. Полнота информации о продуктивном пласте и повышение эффективности разработки // Материалы расширенного заседания ЦКР Роснедр (нефтяная секция), 4-5 декабря 2007: сб. докладов. - М.: НП НАЭН, 2008. - С. 78-89.

4. Ланина О.В., Соколов С.В., Чусовитин А.А. Сравнение эффективности систем разработки подгазовой зоны Самотлорского месторождения // Нефтяное хозяйство. - 2013. - № 2. - С. 2-4.

5. Владимиров И.И., Спивак С.И. Математическое моделирование процессов извлечения нефти при разработке глиносодержащих коллекторов горизонтальными скважинами // Материалы 4-й науч.-техн. конф. молодых специалистов ООО «РН-УфаНИПИнефть», 3-5 марта 2010 г. - Уфа, 2010. - С. 43-47.

6. Владимиров И.И., Задорожный Е.В. Математическое моделирование процессов нефтеизвлечения при разработке горизонтальными скважинами коллекторов с повышенным содержанием глинистых минералов // Автоматизация, телемеханизация и связь в нефтяной промышленности. - 2011. - № 10. - С. 45-47.
7. Антонов М.С., Родионова И.И., Фатхлисламов М.А., Хисаева Д.А. Зависимость эффективности нефтевытеснения из пластов с глинистыми прослоями от положения ствола горизонтальной нагнетательной скважины // Нефтепромысловое дело. - 2012. - № 1. C. 53-56.

8. Сопоставление показателей выработки запасов нефти из пласта при полном и частичном затухании фильтрации в глинистых прослоях / А.Н. Лазеев, И.И. Родионова, Д.А. Хисаева, М.Н. Шаймарданов // Нефтепромысловое дело. - 2012. - № 1. - С. 50-53.

9. Задорожный Е.В. Особенности разработки слоистонеоднородных глинистых коллекторов пласта $\mathrm{AB}_{1}^{1-2}$ Самотлорского месторождения // Нефтепромысловое дело. - 2012. - № 12. - С. 10-14.

10. Исследование эффективности размещения горизонтальных и вертикальных скважин в залежах слоистого геологического строения / И.В. Владимиров, Н.И. Хисамутдинов, Е.В. Задорожный, В.В. Литвин // Оборудование и технологии для нефтегазового комплекса. - 2011. - № 5. - С. 8-12.

11. Шаймарданов М.Н. Оценка влияния глинистости коллектора на КИН при разработке залежи системой вертикальных скважин // Автоматизация, телемеханика и связь в нефтяной промышленности. - 2011. - № 11. - С. 40-44.

12. Изучение процесса заводнения тонкослоистых многослойных коллекторов / М.Н Шаймарданов, Р.Г. Сарваретдинов, Д. Сагитов, М.А. Виноходов, С.Д. Глебов // Нефтегазовое дело. - 2013. - № 3. - С. 86-90. 
13. Хабаров А.В., Волокитин Я.Е. Методика комплексного анализа данных керна и ГИС с целью литологической классификации терригенных коллекторов // Каротажник. - 2009. - Вып. 189. - С. 83-128.

14. Enhanced reservoir description: using core and log data to lolentify Hydralic (F-low) Units and predict permeability in uncored intervaig/wells / J.O. Amaefile, M. Altunbay, T. Diebbar (et al.) // Society of Petroleum Engineers. - 1993. - 205.

15. Волокитин Я.Е., Хабаров А.В. Комплексная методика оценки коэффициента нефтененасыщенности гетерогенных коллекторов // Каротажник. - 2009. Вып. 189. - С. 143-166.

16. Аржиловский А.В., Бикбулатова Т.Г., Костюченко С.В. Опыт моделирования Самотлорского месторождения: проблемы и перспективы // Нефтяное хозяйство. -2010 . - № 11. - С. 46-50.

17. Михайлов Н.Н. Остаточное нефтенасыщение разрабатываемых пластов. - М.: Недра, 1992. - 270 с.

18. Физико-геологические проблемы остаточной нефтенасыщенности / Н.Н. Михайлов, Т.Н. Кольчицкая, А.В. Джемесон [и др.]. - М.: Недра, 1993. - 352 c.

19. Михайлов Н.Н., Варламов Д.П., Кленков К.А. Моделирование влияния систем расстановки скважин на остаточное нефтенасыщение заводненных пластов // Бурение и нефть. - 2004. - № 1. - С. 13-15.

20. Displacement of gas from porous media by water/ M.W. Legatski, D.L. Katz, M.R. Tek, R.L. Gorring,
R.L. Nielsen // Fall Meeting of the Society of Petroleum Engineers of AIME, 11-14 October, Houston, Texas, 1964. - Houston, 1964. - DOI: 10.2118/899-MS.

21. Исследование условий формирования остаточной нефтенасыщенности в полимиктовых коллекторах Западной Сибири / Н.А. Черемисин, В.П. Сонич, Е.Ю. Батурин, В.А. Дроздов // Нефтяное хозяйство. - 1997. - № 9. - С. 40-45.

22. Дворак С.В., Сонич В.П., Николаев Е.В. Закономерность изменения нефтенасыщенности в газовых шапках Западной Сибири // Повышение эффективности разработки нефтяных месторождений Западной Сибири. - Тюмень: СибНИИНП, 1988. - 163 с.

23. Физические основы повышения эффективности разработки гранулярных коллекторов / Н.А. Черемисин, В.П. Сонич, Ю.Е. Батурин, Н.Я. Медведев // Нефтяное хозяйство. - 2002. - № 8. C. $38-41$.

24. Технология оптимизации системы разработки объекта $\mathrm{AB}_{1}^{1-2}$ Самотлорского месторождения / Л.С. Бриллиант, А.А. Клочков, А.Г. Выдрин [и др.] // Нефтяное хозяйство. - 2010. - № 10. - С. 82-84.

25. Ahmed T. Reservoir engineering handbook. Huston: Gulf professional publishing, 2000. - 1211 p.

26. Влияние ГРП на выработку неоднородного по проницаемости участка пласта / И.В. Владимиров, Н.И. Хисамутдинов, А.В. Аржиловский, А.А. Чусовитин, Р.А. Гнилицкий // Нефтепромысловое дело. - 2012. № $1 .-$ C. $68-71$.

Please cite this article in English as:

Chusovitin A.A., Timchuk A.S., Grachev S.I. Study of geological and technological model of complex reservoirs of Samotlor field oil and gas deposits. Bulletin of PNRPU. Geology. Oil \& Gas Engineering \& Mining, 2016, vol.15, no.20, pp.246-260. DOI: 10.15593/2224-9923/2016.20.5

Просьба ссылаться на эту статью в русскоязычных источниках следующим образом:

Чусовитин А.А., Тимчук А.С., Грачев С.И. Исследование геолого-технологической модели сложнопостроенного коллектора нефтегазовой залежи Самотлорского месторождения // Вестник Пермского национального исследовательского политехнического университета. Геология. Нефтегазовое и горное дело. - 2016. - Т.15, №20. - C.246-260. DOI: 10.15593/2224-9923/2016.20.5 